\title{
Duelo de titanes: tensiones entre India y China
}

\section{Laura Gatto ${ }^{1}$}

USALI CARI

\section{Contribución en la \\ Sección Política Internacional}

La novena cumbre de los BRICS, llevada a cabo enXiamen, China, al inicio de septiembre de 2017, fue el escenario del primer encuentro bilateral sustantivo entre representantes de China e India (ambos potencias nucleares), tras el incidente de Doklam. En ese marco, el Secretario de Asuntos Exteriores indio, S. Jaishankar, señaló que el encuentro entre el Primer Ministro Modi y el Premier chino, Xi Jinping, reafirmó la idea de que tener buenas relaciones forma parte del mutuo interés, siendo necesario contar con una mayor comunicación entre el personal de defensa y seguridad de ambos países. Tal comunicación durante la misma cumbre, fue parte de un conjunto de señales y expresiones por parte de ambos gobiernos, en dirección a bajar el tono de la tensión entre ambos, precedida por el acuerdo acerca de una "pronta desconexión" de las fuerzas militares de ambos países en la zona en disputa en el Himalaya, hacia fines de agosto (Miglani y Blanchard, 2017).

Al respecto de este incidente, India sostiene que el problema se inició ante su oposición a que los chinos construyeran un camino a través de la zona montañosadisputada por China y Bután-(cerca de un punto particularmente vulnerable de India) y que su envío de tropas a la zona obedeció a que la actividad militar china allí constituía una amenaza a la seguridad de su región noreste (y a la soberanía de Bután). El episodio se remonta a una convención de 1890 entre el Imperio Qingy laentonces India británica, y los acuerdos posteriores, que incluyen un acuerdo público de 2012, en el cual India afirma que China acordaría resolver disputas pendientes en consulta con los terceros interesados (en este caso, Bután, país con el que China está en negociaciones para resolver sus cuestiones limítrofes, desde la década del '80) (TheEconomic Times, 2017; Penjore, 2004).

Cabe recordar que en 1950, India se convirtió en el primer país no socialista en establecer relaciones diplomáticas con la República Popular China, dándose la primera visita oficial de JawaharlalNehru, en 1954, aunque las diferencias limítrofes estuvieron siempre presentes (Ahmad Dar y Ahmad, 2014; Ranjan, 2016).

\footnotetext{
${ }^{1}$ Licenciada en Estudios Orientales (USAL), miembro del Grupo de Trabajo sobre India y Asia del Sur, del Comité de Asuntos Asiáticos, del Consejo Argentino para las Relaciones Internacionales (C.A.R.I.) y miembro de CARI Joven.
} 
Tras la Primera Guerra Indo-paquistaní en 1947, la frontera entre China e India se modificó al hacerse China de un territorio en Cachemira, reclamado por India, ampliándose su frontera común en seiscientos kilómetros, de un total de aproximadamente dos mil kilómetros divididos en tres sectores: este (comprende seiscientos cincuenta kilómetros y abarca China, India, Bután y Myanmar, junto con el sudeste de Tíbet y la provincia de Arunachal Pradesh en India), centro (abarca cuatrocientos cincuenta kilómetros y la zona occidental de Tíbet y Kimachal Pradesh y Uttar Pradesh, en India) y oeste (se refiere a seiscientos kilómetros en la región de Xinjiang y LadakhRange en Cachemira).

En 1962, se produjo la denominada Guerra sino-india, a raíz de incidentes por Nathu La Pass, en la frontera entre el estado indio de Sikkim y Tíbet bajo control chino, que implicaría una victoria china, ante el rápido accionar de sus fuerzas. Al respecto, Pardesi (2012) sostiene que los tresfactores que llevaron a la decisión de China de atacar a la India en ese momento (el estatus del Tíbet, la militarización de su frontera sin resolver y los temores decontención) continúan presentes en la actualidad, aunque ligeramente modificados.

Mientras desde 1981, ambos países han sostenido conversaciones regulares sobre cuestiones fronterizas, en 1993, firmaron el Acuerdo para el Mantenimiento de la Paz y la Tranquilidad a lo largo de la Línea de Control Efectivo y en 1996 firmaron el Acuerdo de Confianza en el Campo Militar, estabilizando la situación en la frontera común.

Finalmente, a pesar de sus manifestaciones de amistad y el crecimiento del intercambio económico entre ambos (que convirtió a China en el primer socio comercial de la India), la visión de ambos aparece como de mutua "competencia colaborativa", en el marco de la existencia de fuertes lazos entre China y Pakistán (que incluso implican el desarrollo de un corredor económico entre ambos, en el contexto de la Iniciativa OneBeltOne Road) (Dasgupta, 2017), de la asociación estratégica de India con Estados Unidos y Japón -que abona a la contención de China-, la presencia y accionar del Dalai Lama y los refugiados tibetanos en India, etc.

Mientras este incidente constituye un eslabón más en la competencia entre los dos gigantes, para el pequeño buffer statede Bután, su actuación podría configurar parte de su futuro (Penjore, 2004).

A ello se suma el tema del agua, que se está convirtiendo en un área importante de preocupación entre ambos estados y para distintos autores será la principal fuente de conflicto entre los dos países en el futuro, atendiendo a la existencia de ríos que fluyen de China a la India y la necesidad de acuerdo sobre el reparto del agua.

\section{Referencias}


Ahmad Dar, B. y Ahmad, S. (2014). Major Bilateral Issues between China and India. Arts and Social Sciences Journal, 5 (1). Recuperado de file:///C:/Users/user/Downloads/major-bilateral-issues-between-china-and-india2151-6200.1000064.pdf

Dasgupta, S. (2017). China-Pakistan Economic Corridor plan is OBOR flagship: Chinese President Xi Jinping. The Times of India/World (15 de mayo). Recuperado de http://timesofindia.indiatimes.com/world/china/china-pakistan-economic-corridorplan-is-obor-flagship-chinese-president-xi-jinping/articleshow/58675255.cms

Miglani, S. y Blanchard, B. (2017). India and China agree to end border standoff. Reuters/World News (28 de Agosto). Recuperado de https://www.reuters.com/article/us-india-china/india-and-china-agree-to-endborder-standoff-idUSKCN1B80II

Pardesi, S. (2012). The Legacy of 1962 and China's India Policy.Journal of Defence Studies, 6 (4), 189-206. Recuperado de http://www.idsa.in/system/files/jds 64 ManjeetSPardesi.pdf

Penjore, D. (2004). Security of Bhutan: Walking Between the Giants. Journal of Bhutan Studies, 10, 108-131. Recuperado de http://www.bhutanstudies.org.bt/publicationFiles/JBS/JBS Vol10/v10-9.pdf

Ranjan, A. (2016). India-China boundary disputes: an overview. AsianAffairs, 47 (1), 101114. Recuperado de http://www.tandfonline.com/doi/abs/10.1080/03068374.2015.1129869?src=recsy s\&journalCode=raaf20

The Economic Times (2017). It's between us and Bhutan: China tells India to back off on Doklam(2 de Agosto). Recuperado de http://economictimes.indiatimes.com/news/defence/its-between-us-and-bhutanchina-tells-india-to-back-off-on-doklam/articleshow/59879103.cms 